\title{
WATER INTAKE APPLET BASED ON HUMAN EXCREMENT
}

\author{
Nadine Swastika ${ }^{1}$, Winda Hasuki², Sava Savero ${ }^{3}$, Putri Gabriella Satya ${ }^{4}$, Arli Aditya Parikesit ${ }^{*}$ ) \\ ${ }^{12345}$ Department of Bioinformatics, School of Life Sciences \\ Indonesia International Institute of Life Sciences \\ https://i3l.ac.id \\ nadine.melody@student.i3l.ac.id 1, winda.hasuki@student.i3l.ac.id 2, sava.savero@student.i3l.ac.id ${ }^{3}$, \\ putri.satya@student.i3l.ac.id ${ }^{4}$, arli.parikesit@i3l.ac.id ${ }^{5}$
}

$\left(^{*}\right)$ Corresponding author

\begin{abstract}
Abstrak
Agar berfungsi dengan baik, tubuh manusia membutuhkan hidrasi yang cukup karena 70\% tubuh manusia dibangun oleh air dengan banyaknya reaksi kimia yang terlibat agar dapat bekerja secara optimal sepanjang hari. Kekurangan air atau hidrasi dapat menyebabkan masalah pada system pencernaan dan ginjal manusia, yang dapat terlihat pada warna urine dan faeses. Makalah ini bertujuan untuk memaparkan ide untuk membuat aplikasi keseharian konsumsi air berbasis pengawasan warna kotoran manusia. Ini mungkin solusi untuk mengintensifkan kemampuan orang menjadi sadar diri saat minum ebih sedikit air dengan mensurvei zat yang dikeluarkan. Metode yang digunakan adalah mengukur satu indikator yaitu antara urine dan feses yang mendeteksi seberapa banyak air yang harus diminum pengguna, yang dapat terlihat pada warna urin dan feces mereka. Namun sebenarnya, kedua indikator kotoran tersebut dibutuhkan untuk mendeteksi seberapa banyak pengguna minum dalam sehari-hari. Jika salah satu dari indikator ini menunjukkan hasil yang buruk, dapat menyebabkan keracunan air atau hidrasi. Aplikasi berhasil dibuat dengan menggunakan Python untuk memberikan masukan terkait asupan air pengguna berdasarkan kondisi zat yang dikeluarkan, dan menunjukkan indicator yang jelas untuk dehidrasi. Dengan demikian, dapat disimpulkan bahwa aplikasi water intake ini dapat mendeteksi fenomena dehidrasi dengan menjadikan kotoran manusia sebagai indikator.
\end{abstract}

Kata kunci: Asupan Air, Dehidrasi, Warna, Kotoran Manusia

\begin{abstract}
To function properly, the human body requires adequate hydration as $70 \%$ of the human body was being built up by water. It acts as a solvent for lots of biochemical reactions to keep our physiological function work optimally throughout the day. Dehydration could cause a disturbance in both the gastrointestinal and kidney systems of human beings, and it could be noticed in the color of both urine and feces. The objective of this paper is to present an idea on how to make a water intake app based on the color indicator of human excrement surveillance. It might be a solution to intensify people's ability to become self-conscious when drinking less water by surveying the excreted substance. The deployed method is to measure one indicator which is between urine and feces detector on how much water should the user drink by observing the color of both their urine and feces. However, both excrement indicators are needed to detect users' drinking amount. If one of these indicators shows a bad result, it could lead to water intoxication or hydration. The application has been successfully created using Python to give feedback for the user's water intake based on the condition of their excreted substance. The Water Intake application has successfully shown a clear indicator for dehydration. It could be inferred that this water intake software could detect the dehydration phenomenon with human excrement as the main indicator.
\end{abstract}

Keywords: Water Intake, Dehydration, Color, Human Excrement

\section{INTRODUCTION}

Water is an inorganic, colorless chemical substance, composed of hydrogen and oxygen elements, which is the most plentiful and necessary compound for all living beings (Aversa, Petrescu, Apicella, \& Petrescu, 2016). All living beings require water in their lives.
Without water, most living beings are only able to survive for several days. Water requirements came from food intake and beverages among healthy individuals. Sufficient water intake is essential for the homeostasis of fluid and electrolyte tests in our body (Jéquier \& Constant, 2010). Thus, dehydration could pose serious health consequences as seen in 
the six-day war of 1967 that caused significant heatstroke casualties of Egyptian soldiers (Grandjean, 2014). Healthy humans regulate daily water intake across their lifespan despite the changes within their biological development as well as exposure to a stressor on hydration status (Popkin, D'Anci, \& Rosenberg, 2010). Things that are considered as daily water intake includes drinking water, water in food, and water in any beverages. Many factors contributed to differences in total body water which contributed to age, gender, activities, and daily routines, all accounted for each person's body composition (Stookey, 2019). Total body water is distributed into different parts of intracellular and extracellular fluid components within the body, containing around $50 \%$ to $70 \%$ of total body water (Sawka, Cheuvront, \& Carter, 2005).

Disturbance in water intake will also affect the human excretion of the body, regardless it's in solid or fluid form. This could also affect the level of hydration which is also increased with the flow of urine and also solid excretion (Rose, Parker, Jefferson, Cartmell, \& Rose, 2015). A study from Arnaud, 2003 based on elderly people concluded that hydration lowers the chance of getting constipated. Another review study by (Perrier et al., 2020), found that the lack of water intake may increase the chance of kidney stones occurring when urine forms crystals due to the lack of substances within the kidney to bladder area. All of these symptoms have a high chance of occurring due to dehydration, and low fluid intake or liquid deprivation in which water intake was only around 2,500 to 500 milliliters per day (Liska et al., 2019). In the realm of computer science, the software that caters for both urine and feces detections are mainly limited to the large-scale system for biomarker detection, and specialized machine-learning-based system for specific disease diagnostics (Fujimoto et al., 1998; Shu, Liu, Xie, \& Ren, 2017). In this regard, there are a lot of improvements and gaps to be a field in this studies, as there is a need for a more general diagnostics measure for human excrement. However, in the life sciences domain, extensive research has been conducted to establish diagnostics for the water dehydration marker in human excrement (Bičanić, Hladnik, Džaja, \& Petanjek, 2019; Cheuvront, Muñoz, \& Kenefick, 2016; Ghasemi, Khorvash, Ghorbani, \& Elmamouz, 2014). Moreover, large-scale diagnostics with a machine learning approach have been established, albeit only for experts (Ford \& McElvania, 2020; Fujimoto et al., 1998; Shu et al., 2017). It should be noted that impaired executive function and cognitive performance for dehydrated people could occur due to water imbalance level (Guo et al., 2020; Malisova, Bountziouka, Panagiotakos, Zampelas, \&
Kapsokefalou, 2013; Riebl \& Davy, 2013; Stachenfeld, Leone, Mitchell, Freese, \& Harkness, 2018). More advanced engineering efforts have been devised for detecting dehydration in toilet systems and water treatments as well (Park et al., 2020; Rose et al., 2015). So, the combination of both domains of computer and life sciences approaches should devise for an easy-to-use diagnostics measure for water intake diagnostics with human excrement as the marker.

An appropriate water intake of around 2.7 liters to 3.7 liters should do well in assisting our bodies to do daily activities during the day (Kenefick \& Sawka, 2007). There are clinical indicators for determining water dehydration in humans, but more efforts towards automatization are necessary (Carmichael, 2011). There is several-water intake reminder software in the market, but without clear urine and feces indicators available (Everyone, 2020; Funn Media, 2020). The paper aims to present an idea of making a water intake app based on human excrement surveillance whether in liquid (pee form) or solid (stool form) with a color indicator. The novelty of our applet is the combination of both pee and stool color indicators with a user-friendly interface. The app could improve people's ability to become more self-aware of their own body needs whether they lack water intake within the body or an adequate amount of water has finally been reached. This is done by observing the color of the urine or the hardness of the fecal substance.

\section{RESEARCH METHODS}

The applet was created with the Python programming language version 3.6 , along with the kivy and kivymd frameworks development (Ivan, Nurdiansyah, \& Parikesit, 2019). The interactive user interface deployment and visual matching form were exposed in the pseudo-code below (Bhat, Wijaya, \& Parikesit, 2019), and the block sequences were deployed in sequences along with the detailed explanations (Block 1 - 16) :

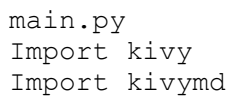

Block 1: The kivy python framework was deployed to enable the multi-touch user interface

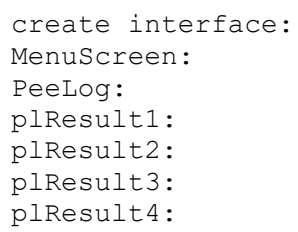


PoOLog:

pooResult1:

pooResult2:

pooResult3:

pooResult4:

History:

Setting:

Block 2: This pseudocode depicts the creation of the menu of the urine colors and feces forms. It also shows the user setting of the applet

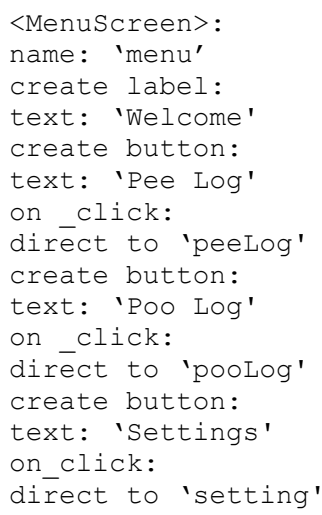

Block 3: This pseudocode explains the contents within the menu screen which consists of "Welcome" text, and four buttons which are between pee log, poo log, and settings.

$<$ PeeLog $>$ :

name: 'peeLog'

create label:

text: 'Select the color of your urine!'

create button:

color: $\mathrm{x}$

on click:

direct to 'PeeResult1'

create button:

color: $y$

on click:

direct to 'PeeResult1'

create button:

color: $\mathrm{z}$

on click:

direct to 'PeeResult1'

create button:

color: a

on click:

direct to 'PeeResult2'

create button:

color: b

on click:

direct to 'PeeResult3'

create button:

color: $\mathrm{c}$

on click:

direct to 'PeeResult4'

create button:

text: 'Back'

on click:

direct to 'menu'
Block 4: When the Pee Log option is chosen on the menu page, users need to pick the color of their urine.

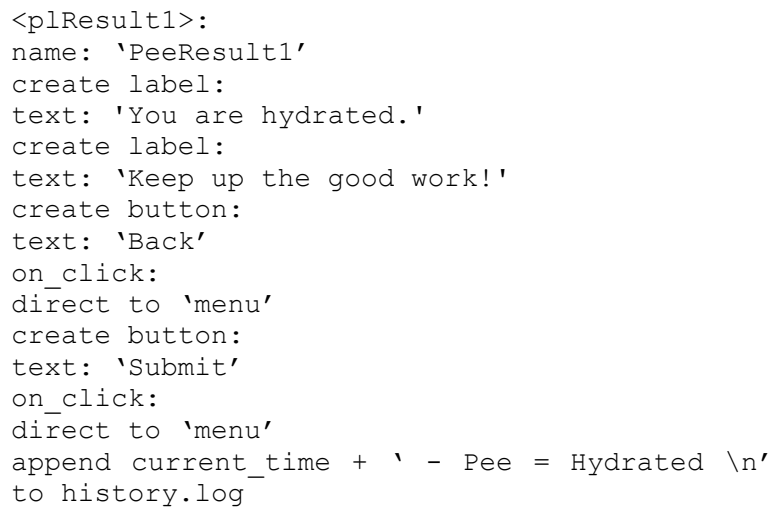

Block 5: This pseudocode shows the output of pee result 1. It will show a message that tells users are very well hydrated. The text result will then be put automatically into the history log.

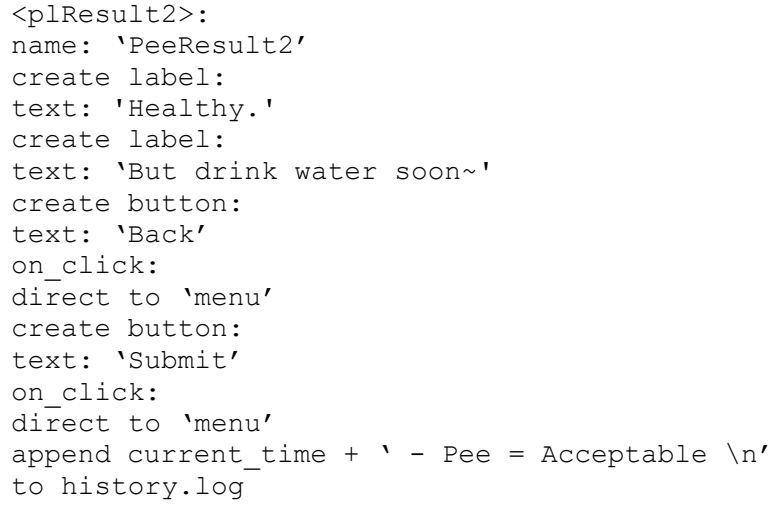

Block 6: This pseudocode shows the output of pee result 2. It will show a message that tells users are hydrated enough but should drink more water. The text result will then be put automatically into the history log.

$<$ plResult3>:

name: 'PeeResult3'

create label:

text: 'You seem to be dehydrated.

create label:

text: 'Please drink more water!'

create button:

text: 'Back'

on click:

direct to 'menu'

create button:

text: 'Submit'

on click:

diřect to 'menu'

append current_time + ' - Pee $=$ Dehydrated $\backslash \mathrm{n}^{\prime}$ to history.log

$<$ plResult4>:

name: 'PeeResult4'

create label: 


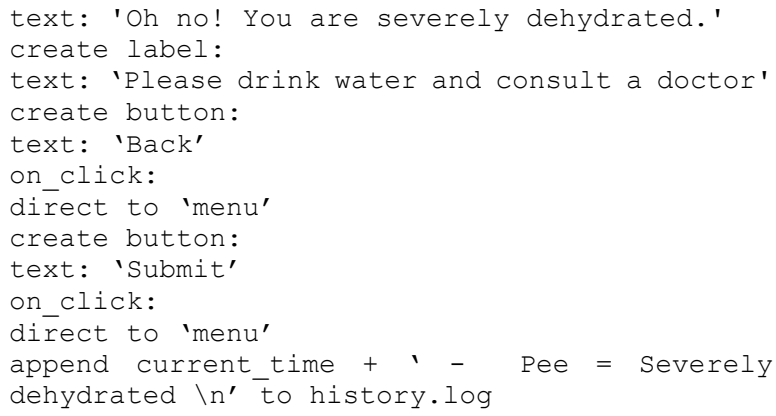

Block 7: This pseudocode shows the other two possible outputs, pee result 3 and 4 . Pee result 3 will show a message that tells users that they are dehydrated, while pee result 4 will tell them that they are severely hydrated. The text result will then be put automatically into the history log.

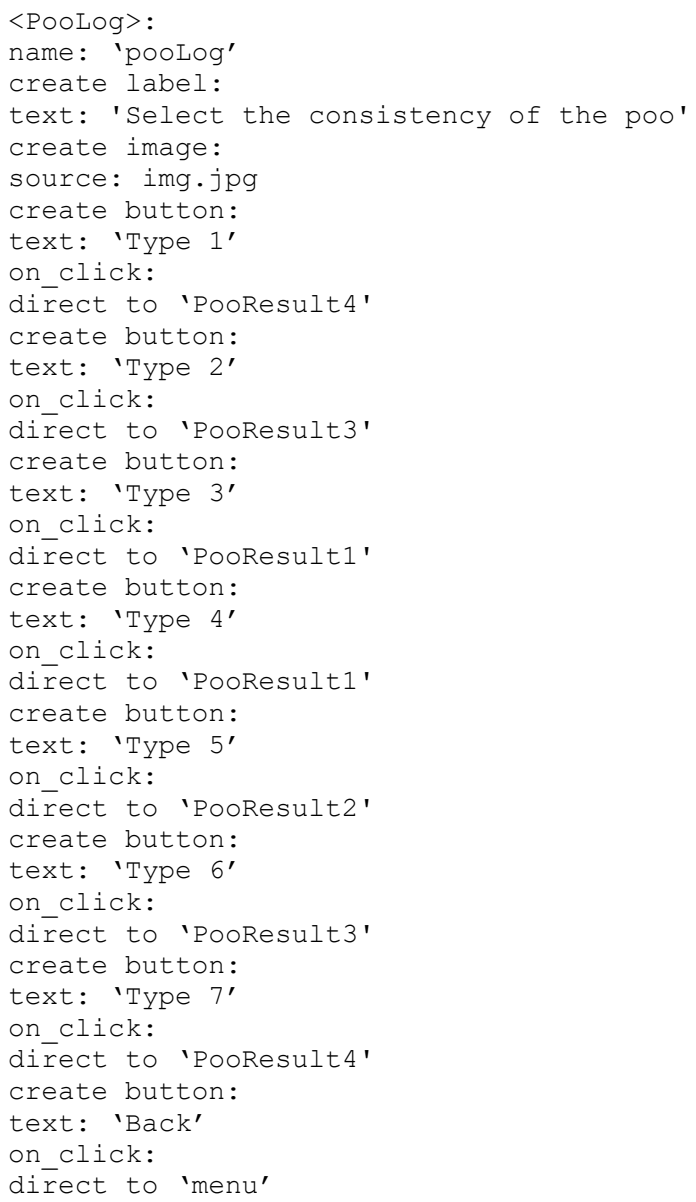

Block 8: When the Poo Log option is chosen in the menu page, users need to pick the consistency of their feces.

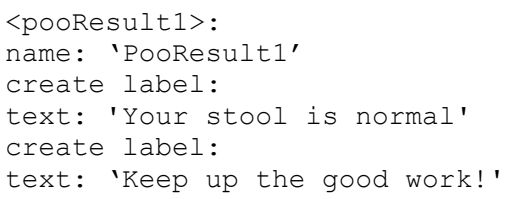

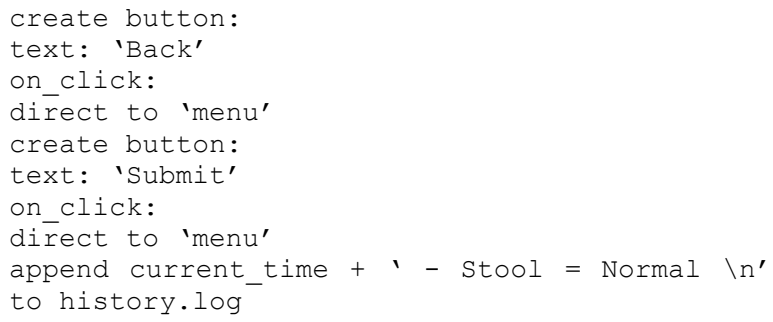

Block 9: This pseudocode depicts the first result for Poo Log, which will tell users that their feces is normal. The result will be sent to the history log.

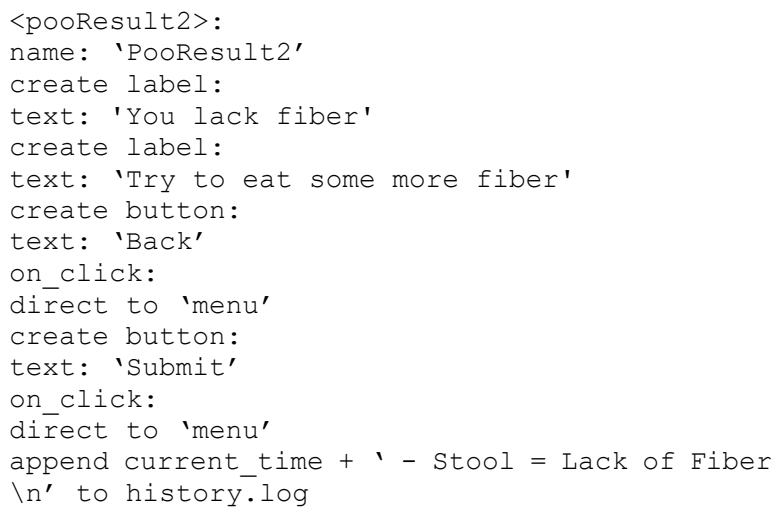

Block 10: this pseudocode depicts the second possible result for Poo Log, which will tell users that their diet seems to lack fiber. The result will be sent to the history log.

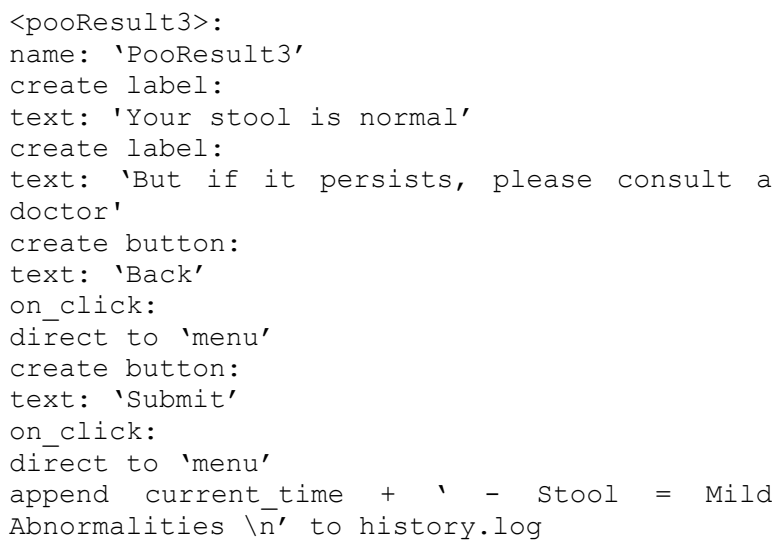

Block 11: This pseudocode shows the third possible result for Poo Log, which will tell users that the consistency of their feces is still normal, but they might need to consult their doctor if they keep getting the same result. The result will be sent to the history log.

$<$ pooResult4 $>$ :

name: 'PooResult4'

create label:

text: 'Your stool is abnormal'

create label:

text: 'Please seek medical attention' 


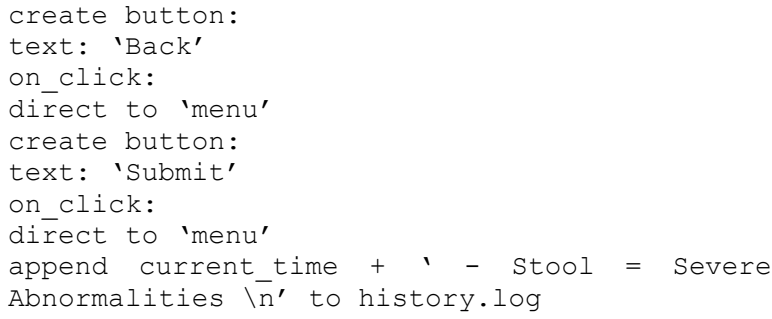

Block 12: This pseudocode shows the fourth possible result for Poo Log, which will tell users that their feces seems abnormal and will need to seek medical attention. The result will be sent to the history log.

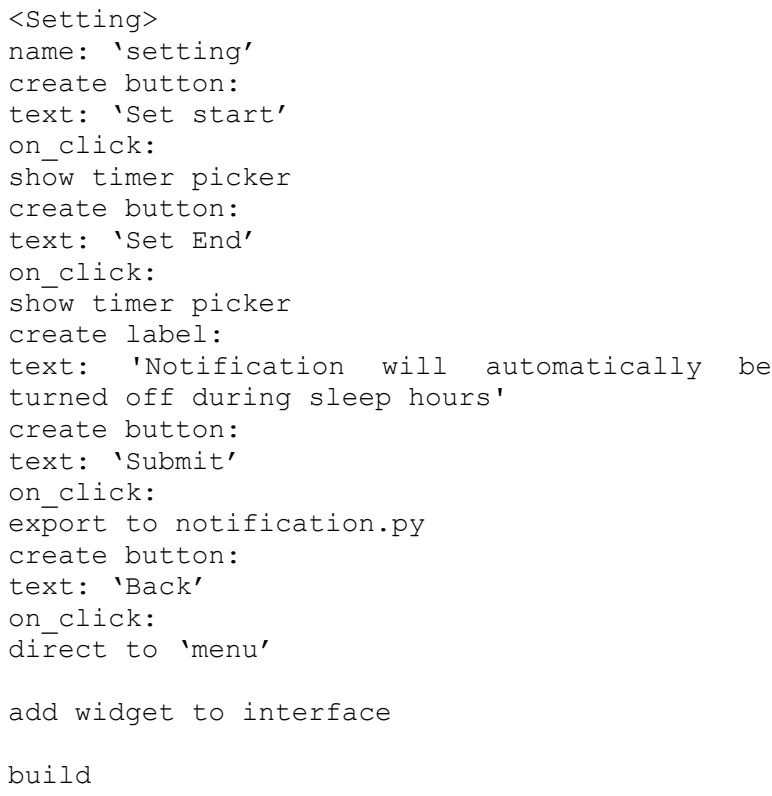

Block 13: This pseudocode explains how the setting page is created. Here, users can set their sleep time. During these hours, the app will not send any notification.

Pseudocode for notification.py

import time

from system import notifier

Block 14: Time is imported to the notification.py.

while True:

current.time = import current.time (\%h: 응ㅇㅇ $)$ if main.settings.setend $>$ current.time main.settings.setstart:

push notification

pause for 7200

else:

loop

Block 15: This pseudocode explains how the app will send notifications two hours after the last time a new input is detected for Pee Log. Notification will not be sent during sleep time (between set start and set end).

notification:

text: 'It's time to log! Don't forget to drink water'

Block 16: The notification will remind the users to $\log$ in and drink water.

Procedure

The 'create interface' function on the pseudo-code above was done to create every display page that has to be created and linked together (Nguyen, 2014). This means that there would be around 13 screens that the user might be able to visit. The parameters of each item always consist of the 'name' and other configuration for each page. 'name' function was used to name the item to be referenced on other pages. 'create label' was used to create a label, with the text displayed on the 'text' parameter. 'create button' would create a button for the user to press on. 'create button' function had a parameter called 'on-click' which defines what the program should do if the user clicks the button 'direct to' function would direct the user to the page it was directed to (Archie, 2019). The 'create image' function was used to import images to be shown in the pages, with the 'source' parameter to define where and what item to be displayed. 'show timer picker' function was used to display the timer picker the android operating system had on stock. 'export to' function indicates that the fields those were field by the user are sent to other files to be processed. 'append to' function was used to add some item to a file. The while loop shows that first, it would import the device time (Meiliana, Septian, Alianto, \& Daniel, 2018). It would then be processed by comparing the device time with the time set by the user. If the device time was between the start and the end time set by the user, the program would push a notification to the user and pause for two hours, and start it over again. If not, the program would start it all over again.

\section{RESULTS AND DISCUSSION}

A mobile hydration application was developed to help people track their water intake based on the condition of their urine and stool. The application was created with kivy, a python package. When the application is opened, the user will see a menu page with three buttons: Pee Input, Poo Input, and Settings. Figure 1 depicted the easy-to-use user menu that is ready to log the excrement visuals, as well as its sets. 


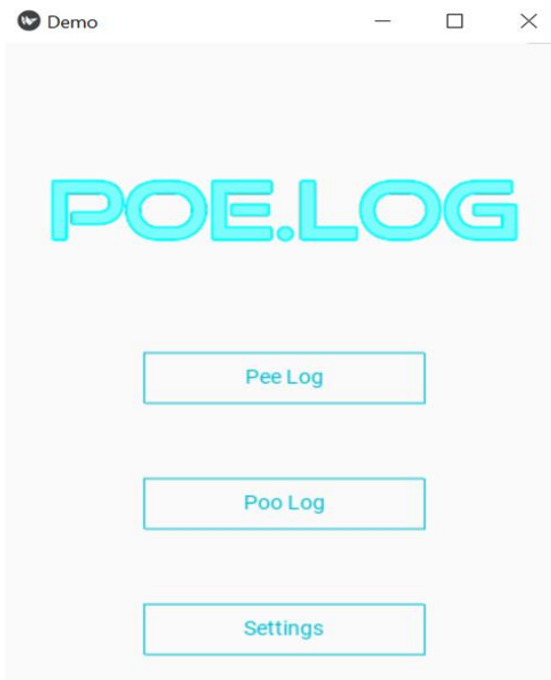

Figure 1 . The menu page. It is using bright colors so will facilitate a visually impaired person. Moreover, the menu has been depicted simply.

The first button, Pee Input, would lead to a page where users can input the color of their urine. On the Pee input page, there are six buttons with different colors (Figure 2). From left to right, the first three buttons represent the ideal or healthy color; the fourth button represents the urine color of someone with mild dehydration; the fifth button represents the urine color of someone who is dehydrated; the sixth button represents the urine color of a severely dehydrated person. Based on the input, the user would be directed to a new page where they can see the implication of the color of their urine and a submit button that would save the user input when clicked. If the user selects one of the first three buttons, they would see a page with a message saying "You are hydrated" and "Keep up the good work" (Figure 3a). When the user chooses the fourth button, a message saying "Healthy! But drink water soon" would be seen (Figure $3 b$ ). The fifth button would lead to a page with a text saying "You seem to be dehydrated. Please drink more water!" (Figure 3c). The last button would show a page with the message: "Oh no! You are severely dehydrated. Please drink water and consult a doctor" (Figure 3d). In this part, it is important to remember that the users should have exposed their good and healthy depiction of their urine visually, especially the upper bright part in figure 2. If they eventually stumble upon the darker visuals below, certain health disorders could be imminent (Liao \& Churchill, 2001)

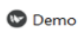

Select the color of your urine!

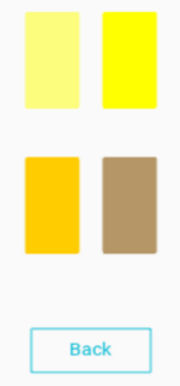

Figure 2. The Pee Log page. It is depicted with different colors of the urine.

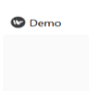

a. The depicted form signifies if the user is healthy and hydrated

- oemo

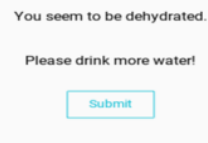

c. The depicted form signifies if the user is dehydrated and should drink more water soon b. The depicted form signifies if the user is healthy but a bit dehydrated
Figure 3 a-d. The possible results for Pee Log. signifies if the user is severely dehydrated and should consult the doctor d. The depicted form 
The second button of the menu page, Poo Input, would show the page where the user can input the condition of their stool. Poo Input works the same way as Pee Input. Seven buttons are representing different shapes and textures of stool (Figure 4). These options are based on the Bristol stool chart. Type 1, with separate and hard lumps, indicates severe constipation; type 2, lumpy and sausage-like, indicate mild constipation; types 3 and 4 indicate a normal stool; type 5, soft blobs with clear-cut edges, indicates lack of fiber; type 6 with mushy consistency indicates mild diarrhea; type 7, liquid consistency and no solid pieces indicate severe diarrhea. The buttons representing types 3 and 4 would lead to a page that says "Your stool is normal" and "keep up the good work" (Figure 5a). Button for type 5 would show a page with a text saying "You lack fiber" and "Try to eat some more fiber" (Figure $5 \mathrm{~b})$. Button for type 2 and 6 will lead to a page with the text: "Your stool is normal. However, if the problem persists please consult a doctor" (Figure 5c). Button for types 1 and 7 will lead to a page with a message saying "Your stool is abnormal. Please seek medical attention" (Figure 5d). Herewith, as seen in figure 4 , the most favorable stool form will be numbers 3 and 4 . The other forms are considered malformed due to dehydration (Chumpitazi et al., 2010).

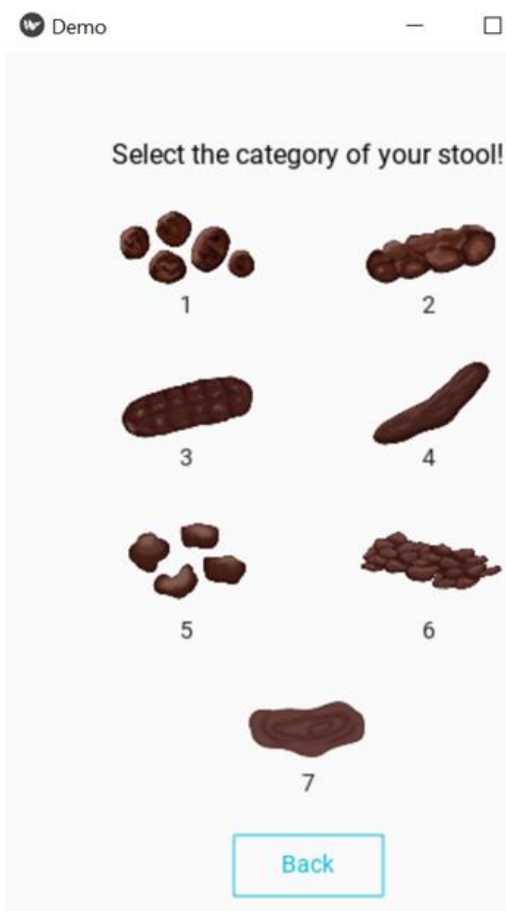

Figure 4. The Poo Log. It is depicted with different shapes of feces.

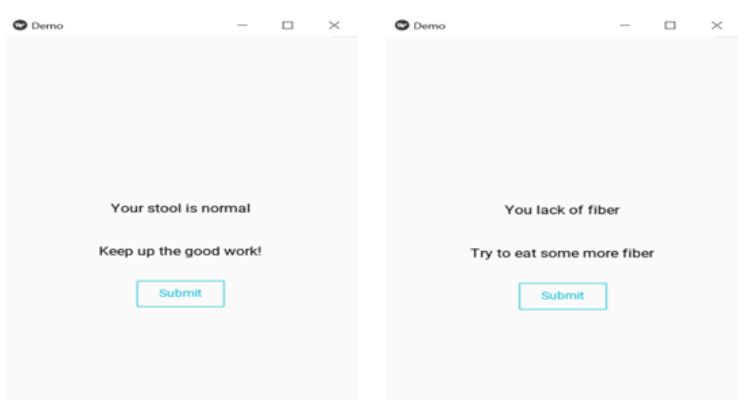

a. The depicted form signifies if the user is having normal stool

b. The depicted form signifies if the user's lack of fiber

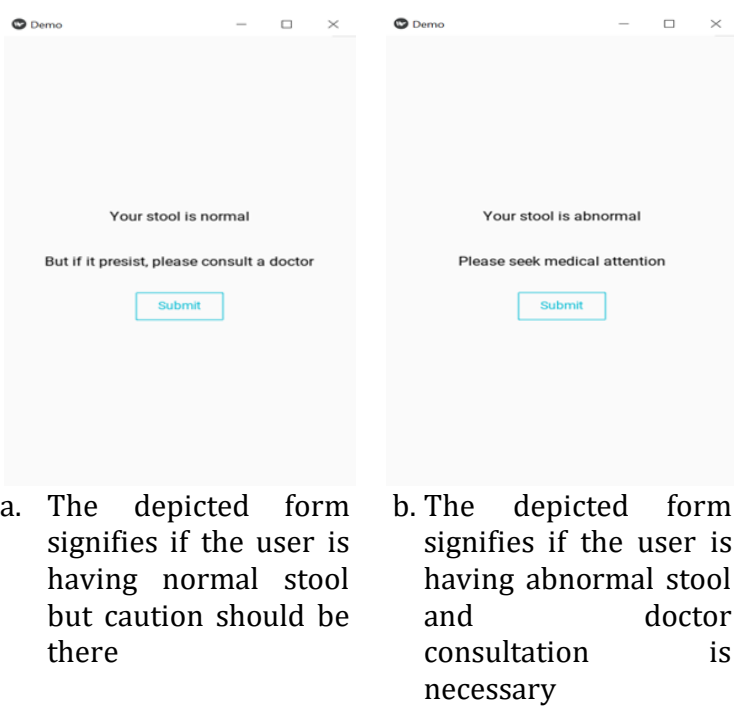

Figure 5 a-d. The possible results for Poo Log.

This application would send a reminder for users to drink water every time there's no submission from Pee Input detected in two and a half hours. The application would also send a notification when no new entry for the Poo Input is found within a week. In settings, users can alter some options (Figure 6). Users can turn off the notification from the Pee Input and/or the Poo Input. As seen in Figure 7, user can also enter their sleep time; within these hours no notification will be sent. 


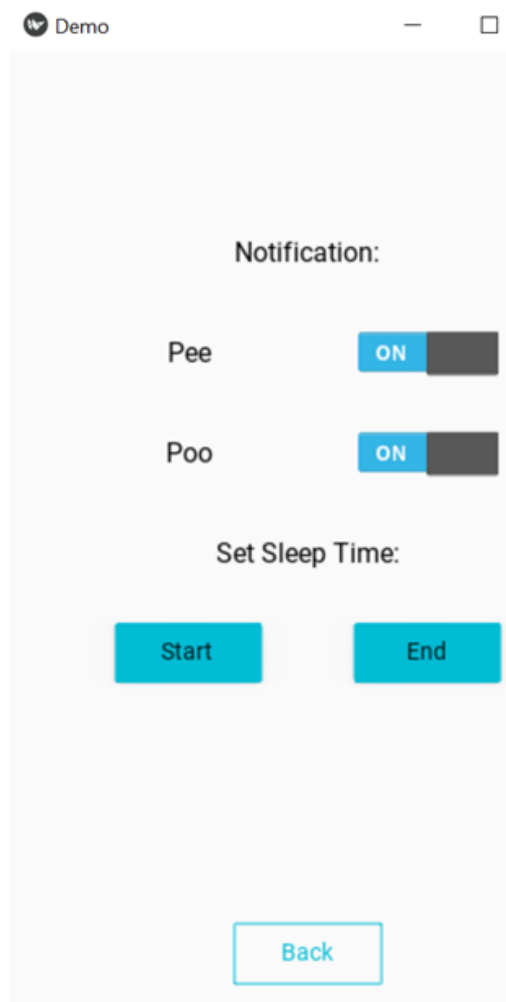

Figure 6. Settings. It is depicted in an easy-tonavigate manner to facilitate user configurations

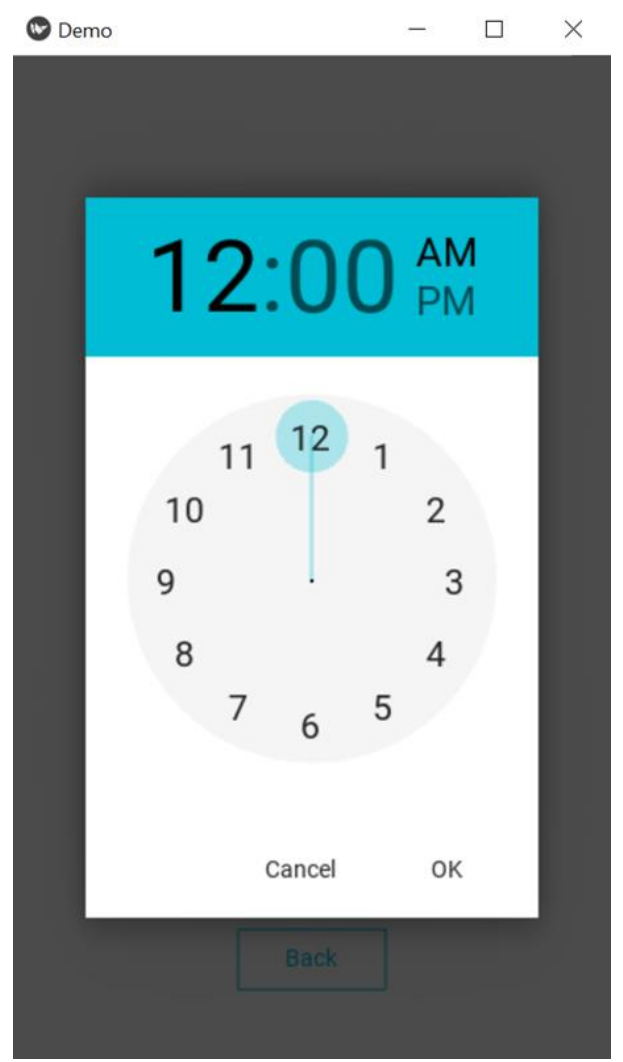

Figure 7. Set sleep time. The conventional system clock was deployed in this regard.
As seen in the user interface depictions, this project can elicit good assistance to ensure sufficient water intake for users. The effect of the application on users' habits has been elicited accordingly, and it is shown that the users enjoy its easiness and userfriendliness. Moreover, it could be concluded that the efficacy of this applet could be considered acceptable to our user.

Our research has elicited a combination of computer and life sciences for developing water intake applets for the users' health annotations. The streamlined user interface has enabled users to optimize this applet for their needs. However, one feature that is currently absent is the unavailability of an expert system, especially the medical one (Kobrinskii, 2020). It is important to provide medical expert judgment to users, so doctors can obtain useful medical annotations before meeting the patient (Broom, 2005). Moreover, visually impaired people will have difficulty in recognizing their feces and urine. In this regard, a more advanced proposal to leverage the gadget's camera to recognize the color and pattern of human excrement with artificial intelligence-based tools could be devised (Fogel \& Kvedar, 2018). Although this kind of instrument has been successfully elicited in cancer diagnostics, further application in this area could be doable (Bernard \& Parikesit, 2020). In the end, the future of the water intake applet for human excrement will be entering the further application of machine learning and big data.

\section{CONCLUSIONS AND SUGGESTIONS}

\section{Conclusion}

This water intake based on human excrement app provides a digital response to the user about their excrement condition after receiving the user's input. It will be expected that the risk of possibly lacking water in the human's body resulting in dehydration can be prevented. By tracking the result in the app, the users could obtain fine-grained information on their water intake level based on the color of the feces and urine. Moreover, it could be inferred that the graphical user interfacebased deployment of the applet has enabled users in curating their own excrement data. The main pitfall of inability to use big data and machine learning should be addressed in the next version of the water intake applet. It is expected that the further improvement of this applet will be the deployment of large-scale user experience data, in order to cater for the machine learning approach of a more complex water-intake related disorder. 


\section{Suggestion}

The significance of using this water intake applet has been elicited to limited respondents. However, the annotation for the rare condition or symptoms in the stool and urine category such as blood presence should be catered in order to facilitate user to seek immediate medical attention. Therefore, the effect on users who use this application and its correlation to their deeplyimpacted hydration status has not yet been determined.

\section{ACKNOWLEDGEMENT}

The authors would like to thank the Institute of Research and Community Empowerment of the Indonesia International Institute for Life Sciences (LPPM I3L) for their heartfelt support. Our thanks also goes to Andamar Pradipta. M.A. from the Community Language Center of i3L for his excellent proofreading of this manuscript.

\section{REFERENCES}

Archie, M. (2019). Creating a Cliché Library for Social Applications (Massachusetts Institute of Technology). Massachusetts Institute of Technology, Cambridge. Retrieved from https://dspace.mit.edu/handle/1721.1/1230 01

Aversa, R., Petrescu, V., Apicella, A., \& Petrescu, I. T. (2016). The basic elements of life's. American Journal of Engineering and Applied Sciences, 9(4), 1189-1197. https://doi.org/10.3844/ajeassp.2016.1189. 1197

Bernard, S., \& Parikesit, A. A. (2020). Artificial Intelligence in Colonoscopy: Improving Medical Diagnostic of Colorectal Cancer. Frontiers in Health Informatics, 9(1), 33. https://doi.org/10.30699/fhi.v9i1.209

Bhat, N., Wijaya, E. B., \& Parikesit, A. A. (2019). Use of the "DNAChecker" Algorithm for Improving Bioinformatics Research. Makara Journal of Technology, 23(2), 72. https://doi.org/10.7454/mst.v23i2.3488

Bičanić, I., Hladnik, A., Džaja, D., \& Petanjek, Z. (2019). The anatomy of orofacial innervation. Acta Clinica Croatica, 58(Supplement 1), 3542.

https://doi.org/10.20471/acc.2019.58.s1.05

Broom, A. (2005). Virtually healthy: The impact of internet use on disease experience and the doctor-patient relationship. Qualitative Health Research, 15(3), 325-345. https://doi.org/10.1177/104973230427291 6
Carmichael, A. (2011). Initial treatment of dehydration for severe acute malnutrition.

Cheuvront, S. N., Muñoz, C. X., \& Kenefick, R. W. (2016). The void in using urine concentration to assess population fluid intake adequacy or hydration status 1,2. The American Journal of Clinical Nutrition, 104(3), 553-556. https://doi.org/10.3945/ajcn.115.129858

Everyone. (2020). Water Reminder - Remind Drink Water. Hanoi: Smart Apps OGS Studio. Retrieved from https://play.google.com/store/apps/details?i $\mathrm{d}=$ com.remind.drink.water.hourly\&hl=en_US $\& \mathrm{gl}=\mathrm{US}$

Fogel, A. L., \& Kvedar, J. C. (2018). Artificial intelligence powers digital medicine. $N p j$ Digital Medicine, 1(5), 1-4. https://doi.org/10.1038/s41746-017-00122

Ford, B. A., \& McElvania, E. (2020). Machine learning takes laboratory automation to the next level. Journal of Clinical Microbiology, 58(4), 16831702. https://doi.org/10.1128/JCM.0001220

Fujimoto, T., Hashimoto, T., Sakaki, H., Higashi, Y., Tamura, T., \& Tsuji, T. (1998). Automated handling system for excretion. Annual International Conference of the IEEE Engineering in Medicine and Biology Proceedings, 4, 1973-1976. Hong Kong: IEEE. https://doi.org/10.1109/iembs.1998.746989

Funn Media. (2020). WaterMinder - Water Tracker and Drink Reminder App. Cicero Ave: Funn Media. Retrieved from https://play.google.com/store/apps/details?i $\mathrm{d}=$ com.funnmedia.waterminder

Ghasemi, E., Khorvash, M., Ghorbani, G. R., \& Elmamouz, F. (2014). Effects of straw treatment and nitrogen supplementation on digestibility, intake and physiological responses of water intake as well as urine and faecal characteristics. Journal of Animal Physiology and Animal Nutrition, 98(1), 100106. https://doi.org/10.1111/jpn.12052

Grandjean, A. (2014). Water Requirements, Impinging Factors, and Recommended Intakes. Geneva.

Guo, Q., Wang, B., Cao, S., Jia, C., Zhao, L., Zhang, Q., ... Duan, X. (2020). Patterns and sociodemographic determinants of water intake by children in China: results from the first national population-based survey. European Journal of Nutrition, 59(2), 529-538. https://doi.org/10.1007/s00394-01901921-w

Ivan, J., Nurdiansyah, R., \& Parikesit, A. A. (2019). Mathematical Problem Solving: One Way to 
Prevent Dementia. Frontiers in Health Informatics, $8(1), \quad 14$ https://doi.org/10.30699/fhi.v8i1.179

Jéquier, E., \& Constant, F. (2010). Water as an essential nutrient: the physiological basis of hydration. European Journal of Clinical Nutrition, 64, 115-123. https://doi.org/10.1038/ejcn.2009.111

Kenefick, R. W., \& Sawka, M. N. (2007). Hydration at the Work Site. Journal of the American College of Nutrition, 26, 597S-603S. https://doi.org/10.1080/07315724.2007.10 719665

Kobrinskii, B. A. (2020). Fuzzy and Reflection in the Construction of a Medical Expert System. Journal of Software Engineering and Applications, 13(02), 15-23. https://doi.org/10.4236/jsea.2020.132002

Liao, J. C., \& Churchill, B. M. (2001). Pediatric urine testing. Pediatric Clinics of North America, 48(6), 1425-1440. https://doi.org/10.1016/S00313955(05)70384-9

Liska, D., Mah, E., Brisbois, T., Barrios, P. L., Baker, L. B., \& Spriet, L. L. (2019). Narrative Review of Hydration and Selected Health Outcomes in the General Population. Nutrients, 11(1), 7099. https://doi.org/10.3390/nu11010070

Malisova, O., Bountziouka, V., Panagiotakos, D. B., Zampelas, A., \& Kapsokefalou, M. (2013). Evaluation of seasonality on total water intake, water loss and water balance in the general population in Greece. Journal of Human Nutrition and Dietetics, 26(SUPPL.1), 90-96. https://doi.org/10.1111/jhn.12077

Nguyen, V. P. (2014). An open source program to generate zero-thickness cohesive interface elements. Advances in Engineering Software, 74(August), 27-39. https://doi.org/10.1016/j.advengsoft.2014.0 4.002

Park, S. min, Won, D. D., Lee, B. J., Escobedo, D., Esteva, A., Aalipour, A., ... Gambhir, S. S. (2020). A mountable toilet system for personalized health monitoring via the analysis of excreta. Nature Biomedical Engineering, 4(6), 624-635. https://doi.org/10.1038/s41551-020-05349

Perrier, E. T., Armstrong, L. E., Bottin, J. H., Clark, W. F., Dolci, A., Guelinckx, I., ... Péronnet, F. (2020, July). Hydration for health hypothesis: a narrative review of supporting evidence.
European Journal of Nutrition, pp. 1-14. Springer. https://doi.org/10.1007/s00394020-02296-z

Popkin, B. M., D’Anci, K. E., \& Rosenberg, I. H. (2010). Water, hydration, and health. Nutrition Reviews, Vol. 68, pp. 439-458. Blackwell Publishing Inc. https://doi.org/10.1111/j.17534887.2010.00304.X

Riebl, S. K., \& Davy, B. M. (2013). The Hydration Equation. ACSM'S Health \& Fitness Journal, 17(6), 21-28. https://doi.org/10.1249/FIT.0b013e3182a9 $570 \mathrm{f}$

Rose, C., Parker, A., Jefferson, B., Cartmell, E., \& Rose, (C) C. (2015). The Characterization of Feces and Urine: A Review of the Literature to Inform Advanced Treatment Technology. Critical Reviews in Environmental Science and Technology, 45, 1827-1879. https://doi.org/10.1080/10643389.2014.10 00761

Sawka, M. N., Cheuvront, S. N., \& Carter, R. (2005). Human Water Needs. Nutrition Reviews, 63(suppl_1), S30-S39. https://doi.org/10.1111/j.17534887.2005.tb00152.x

Shu, Z., Liu, G., Xie, Q., \& Ren, Z. (2017). A method of urine detection based on front vision and image recognition. Proceedings - 2016 9th International Congress on Image and Signal Processing, BioMedical Engineering and Informatics, CISP-BMEI 2016, 402-405. Datong: Institute of Electrical and Electronics Engineers Inc. https://doi.org/10.1109/CISPBMEI.2016.7852744

Stachenfeld, N. S., Leone, C. A., Mitchell, E. S., Freese, E., \& Harkness, L. (2018). Water intake reverses dehydration associated impaired executive function in healthy young women. Physiology and Behavior, 185(1), 103-111. https://doi.org/10.1016/j.physbeh.2017.12.0 28

Stookey, J. D. (2019). Analysis of 2009-2012 Nutrition Health and Examination Survey (NHANES) Data to Estimate the Median Water Intake Associated with Meeting Hydration Criteria for Individuals Aged 12-80 Years in the US Population.

https://doi.org/10.3390/nu11030657 